\title{
PUBLIC AND FISCALITY: FACTS AND UNKNOWNS
}

\author{
Elena FLORIȘTEANU*, Dragoş FLORIŞTEANU** \\ *“Nicolae Bălcescu" Land Forces Academy, Sibiu, Romania, \\ **EY, Romania, Bucharest, Romania \\ elena_floristeanu@yahoo.co.uk, dragos.floristeanu@ro.ey.com
}

\begin{abstract}
Taxes on physical and juridical persons constitute a permanent source of income for the authorities, income that is used to cover public expenses. As the need for public financial resources is growing permanently, a decrease in the tax levels can cause confusion or even public controversy. However, changes brought in the current fiscal legislation have brought a series of decreases (theoretically substantial) of the fiscal obligations owed by the tax payers. Thus, it is natural to try and identify the potential benefits or consequences of the fiscal relaxation that has occurred. Moreover, it can be established if there is a possibility to replace eventual losses of resources from the targeted taxpayers with tax charges that affect other financial actors.
\end{abstract}

\section{Keywords: fiscal policy, fiscal income, contributions, tax cuts}

\section{Introduction}

Fiscal obligations, specifically their level and supportability, are often invoked in discussions regarding the possibility of increasing financial resources that are necessary to the state for financing public needs. In most cases, the government (which establishes the fiscal policies) is facing a fiscal dilemma: what measures with a fiscal character can be applied in a set economic and social context so as not only a satisfactory level of resources is collected, but also a durable economic growth is achieved and taxpayers don't feel suffocated by the fiscal burden established by law.

The fiscal obligations, often reduced to the term of fiscality, are considered a "necessary evil" [1], and are reflected in the assemble of duties established through law to the taxpayers, physical or juridical persons, as part of the financial policy of every state.
To highlight the necessity of using fiscality to achieve a balance between the interests of the state and of taxpayers, Dan Grosu Saguna said that "the biggest and prudent science of fiscality promoted by the government is in knowing to secure the state income, of society, without this becoming a burden or a serious harm to private interests and of the individual patrimony of physical and juridical persons" [2].

The complexity of the concept of fiscality determines an approach from both a juridical and economic perspective. Regarded purely through economic terms, fiscality "represent and ensemble of economic processes in monetary form to mandatory redistribute GDB from physical and juridical persons to the disposition of the state to cover the needs for consumption with public character, which implies the interconditionality between procuring and 
allocation/spending of the respective resources" [3].

The fiscal policy is built depending on the needs and public services that are the states responsibility of financing, correlated with the objectives of economic and social development pursued by the political power and with the realities of the internal and international economic environments at a certain time and their future evolution perspectives.

As the French economists Allain Barrère shows "the financial policy must be indissoluble connected to the economic policy" and the objectives of financial policies should "favor the economic progress through public finances, to regulate the conjuncture through taxes and investments and to realize fiscal justice by considering the contributive possibilities" [4].

The method through which fiscal obligations are established, public income is collected and the way in which it is utilized is a reflection of the financial policy of the state, and in a narrower frame, a materialization of the fiscal policy adopted by it.

\section{The fiscal policy as a base of public financial resources}

In the specialty literature, there are different opinions regarding the content and the role of the financial and fiscal policy (A. Fantini, 1959; P.A. Samuelson, 1967; I. Vacarel, 1999 et.) each of these accentuating either regulation that has the purpose of collecting financial resources or the aspects regarding the redistribution of resource through different means in order to support public expenses.

One of these diverse opinions is that of Prof. Gheorghe Filip which refers to the fiscal policy as a component of financial policy, considering that it represents "the totality of methods, means, forms, instruments and institutions used by the state in procuring fiscal resources and utilizing them for financing public actions and influencing economic and social life. It contains, in principle, the problematic of taxes and that of public expenses." [5].

An in depth look at the concept of fiscal policy can also be found in the Dictionary of economy that has appeared in 2001 as the result of the cooperation of a numerous collective of authors, from which $\mathrm{Mr}$. Enache Constantin also took part. In defining the fiscal policy, he highlights both the componence as well as the conditions and purpose that is pursued in its application, showing that "it's basis is constituted by the criteria of fiscal efficiency, meaning the necessity to obtain a yield that is maximized; it must ensure greater public revenue, while also encouraging economic affairs, investments and promoting equity in contributions to income, with ensuring social protection" [6].

In order to achieve the goals, set through fiscal policy, it is envisaged that at establishing and collection of taxes and duties the possible fiscal optimum is identified, considering not only the economic period but also the particularities of the tax payer population: resistance to taxes, fiscal education and fiscal civicism. These aspects are particularly important as the affect the supportability level of fiscal obligations and compliance with payments. In support to the previous statement, relevant research in the field (such as Laffer's curve) shows that in the pursuit of higher level of resources, the contrary situation can be reached, respectively the diminishing of collected income due to the reduction of the taxable base, determined by payment elusion from taxpayers unsatisfied with their attributed fiscal burden [7].

As it is known, the fiscal policy is built while considering public expenses. However, the volume of public expenses necessary to cover the general needs assumed by the state, is situated, constantly, over that of the collected resources (multiple needs - limited resources). As the 
largest part of public income is consisted of fiscal revenue, there is a risk that in the pursuit of resources a greater volume of revenue through increased fiscalization is sought, an event that can affect the very sources of provenience, respectively the real economy. That is why it is necessary that at establishing public expenses the predicted economic growth is considered thus, determining the volume of the collected financial resources.

The interdependency relation between economic growth and public expenses as a percentage of GDP was demonstrated with the help of "U" shaped curve, "the BARS curve", a name which contains the initials of the economists that have elaborated it (Barro, 1989; Armey, 1995; Rahn and Fox, 1996; Scully, 1994, 1995). According to Armey (1995), a high level of public expenses determines the growth of the fiscal burden, which in turn can affect the growth rate of the economy. The conclusion reached is that an optimum point of fiscality exists - beyond which the economic growth is negatively affected, and a point of increase in fiscal collection, upstream of that point, which encourages economic growth [8].

Indeed, in a study published under the aegis of OECD in which the impact of fiscality on revenues and economic growth was followed, with the help of simulations realized by applying econometric models, it is estimated that a reduction in the rate of fiscality (as a $\%$ of GDP) with 10 percentage points can favor an annual economic growth between $0.5 \%$ and $1 \%$ [9].

For fiscal policies to achieve their pursued role, one economist, Mr. Blanchard supports the adoption of a sustainable fiscal policy, by which he understands those policies which do not lead to an explosive growth in the state's indebtedness level, or following which no measures of no measures are taken to increase tax, drastically reduce public spending, monetize the budget deficit or repudiate public debt [10].

Building a framework for fiscal sustainability implies, in the opinion of KPMG International specialists, a set of basic elements that should include the following [11]:

- balanced fiscal policies to govern for the common good of current and future generations, within the constraints of economic accessibility, national security priorities, social cohesion imperatives and environmental sustainability;

- clearly defined and measurable objectives, established around key fiscal aggregates, to monitor the progress of fiscal sustainability;

- a vision of budgetary, economic and intergenerational cycles: whereas there is a clear and current recognition that public finances and budgetary provisions require a more detailed analysis of fiscal sustainability, covering not only the budget cycle (1-5 years), but also the economic cycle (6 years) and the intergenerational cycle (10+ years);

- fiscal sustainability frameworks should include measurable and defined key performance indicators that can be used to monitor sustainable fiscal progress

- appropriate, committed and sustained implementation of a fiscal sustainability framework that will improve public finances for both current and future generations;

- adequate institutional mechanisms and objectives to ensure sustained implementation throughout the policy cycle;

- coordination of regulatory systems and institutional frameworks of the financial system, tax policies and practices.

\section{Reflecting the level of taxation. Particularities for Romania}

This analysis of fiscality at a Romanian level comes at a time in which fiscal relaxation measures are implemented concurrently with an increase in public 
expenses due to an increase in the level of pensions and salaries in the public sector. In this context, a few measures stand out:

- reducing the fiscal pressure exerted on employers by reducing the contribution due from them to compulsory social insurance by $0.5 \%$ starting on 01.10 .2014 ;

- application from the $1^{\text {st }}$ of June 2015 of a reduced rate of $9 \%$ VAT on food, including beverages, except for alcoholic beverages intended for human and animal consumption (following the application of this measure, a $12 \%$ reduction on these products would be anticipated);

- the reduction of the standard VAT rate from $24 \%$ to $20 \%$ on 1 January 2016 , together with a $9 \%$ to $5 \%$ reduction in the VAT rate for the delivery of textbooks, books, newspapers and some magazines, and for services such as access to castles, museums, cinemas, etc.;

- reducing the standard VAT rate by $20 \%$ to $19 \%$ on 1 January 2017 ;

- the exemption from corporate tax in the first ten years of activity of companies dealing exclusively with innovation and $\mathrm{R} \& \mathrm{D}$ activities;

- a 16\% income tax pension exemption, up to a ceiling of 2,000 lei

- eliminating the retention of social security contributions to health (CASS) for pension revenues, the payment of the contribution being borne by the state budget;

- the abolition as from 1 February 2017 of the calculation of the contribution to statutory pension insurance due by employees of the calculation base of $5 \mathrm{x}$ average gross salary in the economy;

- the increase of the pension point from January 1,2017 by $5.25 \%$, reaching 917.5 lei, and by $9 \%$ as of July 1, 2017, thus reaching 1,000 lei;

- the increase from 1 January 2016 of the gross monthly salary income, up to which the personal deductions set as fixed amounts in the Fiscal Code are granted, to 1.500 lei;

- the increase of minimum wages in the country guaranteed in payment, from 500 lei in the year 2008 to 1,250 lei starting with the $1^{\text {st }}$ of May 2016 and up to 1,450 lei from the $1^{\text {st }}$ of February 2017; ;

The series of fiscal changes is of course ampler, but it can be clearly seen that both tax burden decreasing measures, for both the employees and employers, and measures increasing employers' costs with labor (especially the increase in minimum wage) have been selected.

What remains to be answered is if the applied cuts with immediate impact on incomes could, subsequently be compensated from the consumption stimulus (arrived through the VAT reduction and the increase of incomes to employees and pensioners) and from the investments that are expected from employers through the diminishing of the fiscal burden and through the granted facilities.

As it is known, and as it will be utilized as follows, the indicator for valuing the progress in regard to collecting internal revenues is the percentage of revenues in GDP, which reports the collected revenues to the economic performance of a country. Concerns regarding Romania, appear amid a public revenue collection level well below the EU 28 average and from the fact that the level of expenses has registered a continuous growth (Table no. 1).

Table 1 The evolution of public revenues and expenditures (\% of GDB)

\begin{tabular}{|l|c|c|c|c|}
\hline & $\mathbf{2 0 1 3}$ & $\mathbf{2 0 1 4}$ & $\mathbf{2 0 1 5}$ & $\mathbf{2 0 1 6}$ \\
\hline Total revenues EU 28 & 45,4 & 45,1 & 44,9 & 44,9 \\
\hline Total revenues Romania & 33.3 & 33.5 & 32,8 & 29,37 \\
\hline Total expenses Romania & 34,5 & 33,8 & 34,2 & 31,9 \\
\hline
\end{tabular}

Government finance statistics - Summary tables, 1/2017; Ministry of Public Finance,

Report on the macroeconomic situation for 2017 and its projection for the years 2018-2020 
From the data presented by Eurostat, it can be observed that at the EU-28 level, total public income has stabilized at aroun $44.9 \%$ of GDP between 2015 and 2016, while in Romania, as revenues were reduced in 2016, expenses also suffered cuts [12].

As far as financing sources for public revenues are concerned, it is worth noting that while in developed countries most of the public financial resources is determined through direct taxes, in developing countries, the main source consists from indirect taxes, especially taxes on consumption (VAT, excises). As a level of revenues, Romania, as well as Slovakia, Bulgaria, Latvia and Lithuania are situated among the countries with the smallest percentages as a percentage of fiscal revenues.

The analisis of revenues at a European level, shows that in contrast to the majority of European Union states in which fiscal revenues have very closes levels as percentage in constituting public revenues, in Romania, the obtained revenues are based on indirect taxes and duties (in table no. 2 direct, indirect and social contributions have been selected).

Table no. 2 Level of tax revenue in EU 28 and Romania (\% of GDB)

\begin{tabular}{|c|c|c|c|c|}
\hline & 2013 & 2014 & 2015 & 2016 \\
\hline \multicolumn{5}{|c|}{ EU-28 } \\
\hline Fiscal revenues & 26.5 & 26.6 & 26.7 & 26.7 \\
\hline Indirect taxes & 13.3 & 13.4 & 13.4 & 13.4 \\
\hline Direct taxes & 12.9 & 12.9 & 13.0 & 13.0 \\
\hline Social contributions & 13.4 & 13.4 & 13.4 & 13.4 \\
\hline .......... & ........... & ........ & ......... & ........ \\
\hline \multicolumn{5}{|l|}{ Romania } \\
\hline Fiscal revenues & 18,58 & 18.90 & 19,85 & 17,74 \\
\hline Indirect taxes & 12.7 & 12.7 & 13.3 & 11.3 \\
\hline Direct taxes & 5.9 & 6.2 & 6.6 & 6.5 \\
\hline Social contributions & 8.6 & 8.5 & 8.1 & 8.1 \\
\hline ........... & .......... & ......... & .......... & ........ \\
\hline
\end{tabular}

Eurostat, Government finance statistics - summary tables 1/2017, p.18; p.114

The data presented above are even more relevant when considering the fact that indirect taxes constitute a more secure stream of revenues for the state budget in comparison to direct taxes, as it is more difficult to avoid payment. Direct taxes allow for a greater redistribution of incomes, are more easily noticed by tax payers, increae the cost of labor and generated aversion to the increase of tax rates both from employers and employees. In their turn, indirect taxes are harder to notice, tax payers are not always aware by the payments done with them, thus aiding the authorities in introducing a phenomenon of fiscal anesthesia by incorporating them in the selling price of the products.

The reduced amount of fiscal revenues collected by Romania is determined mainly by factors economical in nature, but a significant share is also derived from the inferior collecting system of our country. Regarding this aspect, it is important to notice that the level of collection is also influenced in a greated measure by hte institutional system in the field of fiscality, especially by the capacity to implement and respect legislation. Also, in order to mobilise internal revenues, it is recommended to increase transparency, simplify fiscality and encourage predicatbility. Through their methods of functioning and implementation, fiscal systems can secure obtaining revenues on sustainable basis in an equitable and efficient mannere.

\section{Conclusions}

Through the promoted fiscal measures, Romania enters in the competition of fiscal 
relaxation, and among other states, tries to lure investors and decrease its preasure on labor. Situated in a continous "search" for resources, through fiscal relaxation applied in the last years, Romania is trying to mobilise revenues and increase the collected volumes. However, a path that can benefit from more attention is that of durable investments coupled with measures to improve the collecting level and decrease fiscal evasion.

\section{References}

[1] M. Şt. Minea, C. F. Costaş, Fiscalitatea în Europa la începutul mileniului III, editura Rosseti, Bucureşti, p. 19-20, 2006.

[2] Şaguna, D.G., Procedura fiscală, București: Oscar Print, p. 50, 1996.

[3] Gheorghe Filip, Finanțe publice, Suport de curs, Universitatea “ Al.I.Cuza Iași”, p.88, anul universitar 2007-2008.

[4] Barrère Allain, Politique financière, 1958, apud. Iulian Văcărel şi colaboratori, Finanţe Publice, Editura Didactică şi Pedagogică, București, pag. 129, 1999.

[5] Gheorghe Filip, "Fiscalitatea și nivelul său relativ", revista Finanțe. Credit. Contabilitate, nr. 8/ 1995.

[6] Angelescu Coralia, Ciucur Dumitru, Dinu Marin, Dobrotă Niţă, ..., Socol Cristian, ...., (Colectiv de autori), Dicționar de economie, Ediția a doua, Editura economică, București, p.338, 2001.

[7] Arthur B. Laffer, The Laffer Curve: Past, Present, and Future, articol publicat pe site-ul fundaţiei Heritage la 01 iunie 2004.

[8] Francesco Forte Sapienza, Cosimo Magazzino, Government Size and Economic Growth in Italy: A Time-series Analysis, European Scientific Journal, edition vol.12, No.7, p.151, March 2016.

[9] Willi Leibfritz, John Thornton, Alexandra Bibbee, Taxation and Economic Performance, OECD Economics Department Working Papers, No. 176, p.11, 1997.

[10] Blanchard Oliver Jean, „Suggestions for a New Set of Fiscal Indicators”, OECD Economics Department Working Papers,No.79, 1990.

[11] John Herhalt și Nick Baker,Walking the fiscal tightrope: a framework for fiscal sustainability in government, KPMG International, p. 6, 2013.

[12] Government finance statistics, Summary tables, 1/2017, Eurostat, p.11. 